\title{
Early transition of the digestive system to exogenous nutrition in domestic post-hatch birds
}

\author{
BY Y. PINCHASOV \\ Department of Animal Science, Faculty of Agriculture, Hebrew University of Jerusalem, \\ Rehovot 76-100, Israel
}

(Received 19 November 1993 - Revised 18 July 1994 - Accepted 21 July 1994)

\begin{abstract}
The effect of early transition of the digestive system to exogenous nutrition was examined in three experiments with growing birds. A nutrient mixture (0.5 ml) of glucose, starch and oil $(1: 1: 0.5$, by vol $)$ was orally administered immediately after hatch to turkey poults (Meleagris gallopavo) having immediate or delayed access to feed (Expt 1). Increasing amounts (0, 0.25 and $0.5 \mathrm{ml})$ of this mixture were administered immediately after hatch to turkey poults (Expt 2), or to broiler chicks (Gallus domesticus; Expt 3). The relative weights of the gastrointestinal tract (GIT) and its ingesta content, and the amylolytic capability of the pancreas were examined during the immediate post-hatch period (to $30 \mathrm{~h}$ ). Oral administration of nutrients immediately after hatching only slightly influenced the growth of the pancreas and its amylolytic activity, but significantly increased GIT weight in both species, in a dosedependent manner. It is suggested that early post-hatching exposure of the digestive system by the forced administration of nutrient mixture induces anatomical and metabolic changes in the digestive system slightly earlier than in birds with late access to feed. This increases GIT content and plasma glucose levels, resulting in enhanced feed consumption and growth promotion.
\end{abstract}

Amylolytic capability: Gastrointestinal tract: Post-hatch birds: Turkey poults

Newly hatched chicks and poults are frequently held for over $24 \mathrm{~h}$ without access to feed and water before placement on a farm (Moran, 1990; Donaldson \& Christensen, 1992; Pinchasov \& Noy, 1993). Early access to feed and water after hatching is important for subsequent performance (Moran, 1990): a linear correlation has been reported between chick placement weight and subsequent growth (Proudfoot, 1982; Whiting, 1984; Wyatt et al. 1985; Warriss et al. 1992). Oral administration of feed in newly hatched birds has been suggested to stimulate mechano- and/or chemoreceptors in the gastrointestinal tract (GIT) (Donaldson \& Christensen, 1992). This presumably results in enhanced feed consumption and has been reported to promote subsequent performance of commercial birds (Kienholz \& Ackerman, 1970; Phelps et al. 1987; Moran, 1990). Results of a previously reported study (Pinchasov \& Noy, 1992) indicated that post-hatch birds which are administered nutrients are significantly heavier at later ages than those that are not, and this result was more consistent in birds with delayed access to feed. Although several hypotheses have been proposed (Phelps et al. 1987; Donaldson \& Christensen, 1992), the reasons for this phenomenon are unknown. It may be hypothesized that oral administration of nutrients immediately after hatching induces anatomical and metabolic changes in the digestive system slightly earlier than in birds with late access to feed. To test this hypothesis the content of the GIT and the amylolytic capability of the pancreas were examined in forced oral-nutrient-administered, post-hatch (to $30 \mathrm{~h}$ ) broiler chicks (Gallus domesticus) and turkey poults (Meleagris gallopavo). 


\section{MATERIALS AND METHODS}

\section{Preliminary study}

Ninety broiler chicks of the Arbor Acres strain, obtained from a commercial hatchery, were divided into five treatment groups of fifteen birds each, and administered $0.5 \mathrm{ml}$ aqueous solution $(50: 100, \mathrm{w} / \mathrm{v})$ of $(a)$ starch and $(b)$ casein or $(c)$ soya-bean oil $(0.2 \mathrm{ml})$ as previously described (Noy \& Pinchasov, 1993). A positive control group $(d)$ was administered $0.5 \mathrm{ml}$ water while a non-intubated group $(e)$ was used as a negative control. The birds were placed in battery cages and provided ad lib. with commercial starter broiler diet. Body weights were monitored for the first week.

\section{Expt 1}

Fifty turkey poults of the Nicholas strain, obtained from a commercial hatchery (no longer than $6 \mathrm{~h}$ out of their shells), were wing-banded, weighed and randomly divided into two administered groups. A nutrient mixture was prepared using aqueous mixtures (50:100, w/v) of glucose and starch (Merck, Darmstadt, Germany) with soya-bean oil (1:1:0.5, by vol), using soya-bean lecithin $(50 \mathrm{mg} / \mathrm{ml})$ as an emulsifying agent. Based on the results of a preliminary study (Noy \& Pinchasov, 1993), half the birds were administered $0.5 \mathrm{ml}$ of the continuously stirred nutrient mixture and intubated into the crop via a repeating pipette, while the remainder were not. Each group was then immediately divided into two subgroups, one of which was provided with immediate access to feed and water while the other was deprived of feed and water for $24 \mathrm{~h}$. The poults were brooded in battery cages in groups of three birds per cage, under continuous artificial lighting. A commercial starter turkey diet was provided ad lib. and feed intake and body weight were monitored.

Necropsy was carried out on six to eight birds per group sampled at hatch (between 0 and $6 \mathrm{~h}$ after hatching) and in the four experimental groups $24 \mathrm{~h}$ thereafter (two administered groups, with or without access to feed). Blood was collected from the heart with a heparinized syringe. The blood was kept cool $\left(0-4^{\circ}\right)$ and centrifuged $(1500 \mathrm{~g}$, $10 \mathrm{~min}$ ), and the plasma was collected and kept at $-20^{\circ}$ until chemical analysis. Then the birds were killed by cervical dislocation, the abdominal cavity was opened and the residual yolk sac, liver and pancreas were removed, weighed and kept frozen $\left(-20^{\circ}\right)$. The GIT was separated into the following segments: crops, ventriculus, upper (duodenum) and lower (jejunum + ileum) small intestine (SI) and caecum. These segments were weighed with and without their contents.

\section{Expt 2}

Fifty turkey poults of the Nicholas strain, obtained from a commercial hatchery, were wing-banded, weighed and randomly divided into three administered groups. The poults were intubated immediately after hatching (no longer than $6 \mathrm{~h}$ after hatching) with $0,0 \cdot 25$ or $0.5 \mathrm{ml}$ of the nutrient mixture described above. They were then transferred into battery cages, brooded in groups of three birds/cage and provided ad lib. with a commercial starter turkey diet. Necropsy was carried out on five to six birds per group, sampled at hatch $(0-6 \mathrm{~h})$ and $24 \mathrm{~h}$ thereafter (three doses). Blood was collected as described above, and the birds were killed by cervical dislocation. The abdominal cavity was opened and the residual yolk sac and pancreas were removed, weighed and kept frozen $\left(-20^{\circ}\right)$. The crop, duodenum and caecum were removed and weighed with and without ingesta.

\section{Expt 3}

Fifty broiler chicks of the Arbor Acres strain, obtained from a commercial hatchery, were treated and administered as in Expt 2. In this experiment necropsy was carried out on six to eight birds per group (three doses). 
Table 1. Preliminary study. Body weights of broiler chicks receiving a single forced administration of nutrients by oral intubation immediately after hatching*

(Mean values with their pooled standard error for fifteen replicates per treatment group)

\begin{tabular}{|c|c|c|c|c|c|c|}
\hline \multirow[b]{2}{*}{ Age (d) } & \multicolumn{5}{|c|}{ Body weight (g) } & \multirow[b]{2}{*}{ SEM } \\
\hline & Starch & Casein & Oil & Water & None & \\
\hline 0 & $40 \cdot 6$ & & & & & \\
\hline 1 & 50.8 & $51 \cdot 3$ & $51 \cdot 5$ & $50 \cdot 7$ & $53 \cdot 3$ & 0.5 \\
\hline 2 & $63 \cdot 3$ & 61.6 & $60 \cdot 3$ & $61 \cdot 1$ & 64.5 & 1.0 \\
\hline 5 & $91^{a}$ & $81^{\mathrm{b}}$ & $82 \cdot 5^{b}$ & $83 \cdot 8^{\mathrm{ab}}$ & $85 \cdot 8^{\mathrm{ab}}$ & 0.8 \\
\hline
\end{tabular}

${ }^{a, b}$ Mean values bearing unlike superscript letters were significantly different, $P<0.05$.

* For details of nutrients and procedures, see p. 472.

\section{Chemical analysis}

Plasma glucose levels were determined by the glucose oxidase (EC 1.1.3.4) method (Diagnostic Kits, Sigma Chemical Co., St. Louis, MO, USA). The activity of pancreatic $\alpha$ amylase (EC 3.2.1.1) was determined by modification of Bernfeld's (1955) procedure, as previously described (Pinchasov \& Noy, 1994). One unit (U) of amylase activity was defined as that hydrolysing $1 \mathrm{mg}$ starch in $3 \mathrm{~min}$ at $37^{\circ}$.

\section{Statistical analysis}

Analysis of variance was carried out on data using the General Linear Models (GLM) procedure of base $\mathrm{SAS}^{\circledR}$ software (SAS Institute, 1985). A non-randomized block model design was used, where nutrient administration and holding time in Expt 1, and dose in Expts 2 and 3, were assigned the main effects. Duncan's multiple range test was used to compare differences between means of the immediate $v$. the pooled $24-30 \mathrm{~h}$ post-hatch birds.

\section{RESULTS}

\section{Preliminary study}

A single post-hatch administration of nutrients influenced body weight during the immediate post-hatch period of broiler chicks (Table 1). At $5 \mathrm{~d}$ of age, significant differences were noted between the starch $v$. the casein- or oil-administered groups, but not $v$. controls. No significant differences in body weight were noted between the water- and non-administered controls.

\section{Expt 1}

A single administration of the nutrient mixture did not influence body-weight gain during the $30 \mathrm{~h}$ period post-hatch (Table 2). However, birds with immediate access to feed and water from both administered and non-administered groups lost significantly less weight than those with delayed access. No significant differences in feed intake were noted between the nutrient-administered and non-administered groups. Birds deprived of feed during the first $24 \mathrm{~h}$ after hatching consumed significantly more feed on day 2 than their immediatefed counterparts. However, their overall consumption to $2 \mathrm{~d}$ of age was lower than that of the latter (Table 2).

GIT relative weight and contents $(\mathrm{g} / \mathrm{kg}$ body weight $(\mathrm{BW})$ ) increased significantly 24-30 h post-hatch in all segments (Table 3 ). Birds with immediate access to feed and water had significantly higher GIT and content weights in most segments (except the crop), as 
Table 2. Expt 1. Body weights and feed intakes of turkey poults fed immediately after hatching (IF) or held for 24-30 h post-hatch, with or without a single forced administration of nutrients*

(Mean values with their pooled standard error for ten replicates per treatment group)

\begin{tabular}{|c|c|c|c|c|c|c|c|c|}
\hline & \multicolumn{2}{|c|}{ Administered } & \multicolumn{2}{|c|}{ Non-administered } & \multirow[b]{2}{*}{ SEM } & \multicolumn{2}{|c|}{$\begin{array}{l}\text { Significance } \\
\text { of } F \text { value }\end{array}$} & \multirow[b]{2}{*}{$\mathrm{A} \times \mathrm{H}$} \\
\hline & IF & Held & IF & Held & & Administered & Held & \\
\hline \multicolumn{9}{|l|}{ Body weight (g) } \\
\hline $0-6 \mathrm{~h}$ after hatching & $65 \cdot 8$ & $65 \cdot 6$ & $64 \cdot 7$ & $65 \cdot 8$ & $1 \cdot 75$ & NS & NS & NS \\
\hline $24-30 \mathrm{~h}$ & $62 \cdot 9$ & $60 \cdot 8$ & 61.4 & $61 \cdot 6$ & 1.05 & NS & NS & NS \\
\hline Body-weight gain (g) & $-2 \cdot 9$ & $-4 \cdot 8$ & $-3 \cdot 3$ & $-4 \cdot 2$ & -0.06 & NS & 0.001 & NS \\
\hline \multicolumn{9}{|l|}{ Feed intake $(\mathrm{g})$} \\
\hline Day 1 & 8.68 & - & 6.61 & - & 1.91 & NS & 0.001 & NS \\
\hline Day 2 & 6.96 & 9.69 & 6.57 & $9 \cdot 72$ & 1.98 & NS & 0.010 & NS \\
\hline
\end{tabular}

A $\times \mathrm{H}$, interaction between administered and held birds; NS, not significant.

* For details of nutrients and procedures, see p. 472.

Table 3. Expt 1. The relative weights of the liver, residual yolk sac and pancreas, pancreatic $\alpha$-amylase (EC 3.2.1.1) activity and gastrointestinal organ weights and their contents in turkey poults fed immediately after hatching (IF) or held for 24-30 h post-hatch, with or without a single forced administration of nutrients ${ }^{\dagger}$

(Mean values with their pooled standard error for ten replicates per treatment group)

\begin{tabular}{|c|c|c|c|c|c|c|c|c|c|}
\hline & \multirow[t]{3}{*}{ At hatch } & \multicolumn{4}{|c|}{$24-30 \mathrm{~h}$ post-hatch } & \multirow[b]{3}{*}{ SEM } & \multirow{2}{*}{\multicolumn{2}{|c|}{$\begin{array}{l}\text { Significance } \\
\text { of } F \text { value }\end{array}$}} & \multirow[b]{3}{*}{$\mathbf{A} \times \mathbf{H}$} \\
\hline & & \multicolumn{2}{|c|}{ Administered } & \multicolumn{2}{|c|}{ Non-administered } & & & & \\
\hline & & IF & Held & IF & Held & & Adm. & Held & \\
\hline \multicolumn{10}{|c|}{ Organ weights (g/kg BW) } \\
\hline Crop & & $5 \cdot 7$ & $5 \cdot 7$ & $5 \cdot 8$ & $4 \cdot 4$ & 0.4 & NS & NS & NS \\
\hline with content & & $6 \cdot 1$ & $6 \cdot 4$ & $6 \cdot 3$ & $6 \cdot 6$ & $0 \cdot 2$ & NS & NS & NS \\
\hline Ventriculus & $28 \cdot 4$ & $39 \cdot 6^{*}$ & $36 \cdot 7$ & $39 \cdot 7^{*}$ & $37 \cdot 6$ & $1 \cdot 3$ & NS & 0.001 & NS \\
\hline with content & $35 \cdot 2$ & $49 \cdot 7^{*}$ & 40.0 & $47 \cdot 1^{*}$ & $40 \cdot 7$ & 1.7 & NS & 0.001 & NS \\
\hline \multicolumn{10}{|l|}{ Small intestine } \\
\hline uppert & $3 \cdot 4$ & $5 \cdot 7^{*}$ & $5 \cdot 3$ & $6 \cdot 5^{*}$ & $4 \cdot 9$ & $0 \cdot 5$ & NS & 0.004 & NS \\
\hline with content & $4 \cdot 6$ & $8 \cdot 3^{*}$ & $7 \cdot 0$ & $7 \cdot 0^{*}$ & $6 \cdot 1$ & 0.4 & NS & 0.004 & NS \\
\hline lowert & $9 \cdot 9$ & $20 \cdot 0^{*}$ & $13 \cdot 0$ & $16 \cdot 7^{*}$ & $13 \cdot 7$ & $1 \cdot 1$ & NS & 0.002 & NS \\
\hline with content & $13 \cdot 0$ & $26 \cdot 7^{*}$ & $16 \cdot 6$ & $19 \cdot 5^{*}$ & 150 & $1 \cdot 2$ & 0.01 & 0.003 & NS \\
\hline Caecum & $3 \cdot 3$ & $4 \cdot 7^{*}$ & $4 \cdot 6$ & $5 \cdot 2 *$ & $3 \cdot 6$ & 0.3 & NS & 0.02 & 0.06 \\
\hline with content & $6 \cdot 7$ & $8 \cdot 3^{*}$ & $7 \cdot 6$ & $7 \cdot 1^{*}$ & $6 \cdot 1$ & 0.5 & $0 \cdot 05$ & NS & NS \\
\hline Liver & $23 \cdot 6$ & $33 \cdot 8 *$ & $31 \cdot 7$ & $31 \cdot 3^{*}$ & $29 \cdot 2$ & $1 \cdot 1$ & $0-063$ & NS & NS \\
\hline Residual yolk & 167 & $82^{*}$ & 116 & $100^{*}$ & 106 & $9 \cdot 4$ & NS & 0.083 & NS \\
\hline Pancreas & $1 \cdot 16$ & $1.65^{*}$ & 1.73 & $1 \cdot 40^{*}$ & $1 \cdot 4$ & 0.15 & 0.086 & NS & NS \\
\hline \multicolumn{10}{|l|}{$\alpha$-Amylase activity } \\
\hline $\mathrm{U} / \mathrm{g}$ & 369 & $14 \cdot 4^{*}$ & $18 \cdot 5$ & $28 \cdot 9^{*}$ & $27 \cdot 1$ & $3 \cdot 4$ & NS & NS & 0.070 \\
\hline$U$ & 26.55 & $1.40^{*}$ & 1.94 & $2 \cdot 24^{*}$ & $2-43$ & 0.42 & 0.036 & NS & 0.015 \\
\hline $\mathrm{U} / \mathrm{kg} \mathrm{BW}$ & $441 \cdot 0$ & $22 \cdot 2^{*}$ & $32 \cdot 9$ & $35 \cdot 9 *$ & $39 \cdot 4$ & $5 \cdot 4$ & 0.074 & NS & 0.007 \\
\hline
\end{tabular}

BW, body weight; $\mathrm{A} \times \mathbf{H}$, interaction between administered and held birds; NS, not significant.

* Mean values were significantly different from those of birds at hatch, $P<0.05$.

$\uparrow$ For details of nutrients and procedures, see pp. 472-473.

$\mp$ Upper small intestine $=$ duodenum; lower small intestine $=$ jejunum + ileum. 
Table 4. Expt 2. Gastrointestinal capacity (organ weights with ingesta), relative weights of the residual yolk sac and pancreas, and pancreatic $\alpha$-amylase (EC 3.2.1.1) activity in $24 \mathrm{~h}$ posthatch turkey poults which received various levels of nutrients in a single administration immediately after hatching $\dagger$

(Mean values with their pooled standard error for five or six birds per treatment group)

\begin{tabular}{|c|c|c|c|c|c|c|}
\hline \multirow[b]{2}{*}{ Dose administered $(\mathrm{ml}) \ddagger \ldots$} & \multirow[t]{2}{*}{ At hatch } & \multicolumn{3}{|c|}{$24-30 \mathrm{~h}$ post-hatch } & \multirow[b]{2}{*}{ SEM } & \multirow{2}{*}{$\begin{array}{l}\text { Significance } \\
\text { of } F \text { value }\end{array}$} \\
\hline & & 0 & $0 \cdot 25$ & 0.5 & & \\
\hline \multicolumn{7}{|l|}{ Organ weights (with ingesta) } \\
\hline \multicolumn{7}{|l|}{ Crop } \\
\hline (g) & 0.40 & $0.36^{*}$ & $0.45^{*}$ & $0 \cdot 50^{*}$ & 0.03 & 0.022 \\
\hline$(\mathrm{g} / \mathrm{kg} \mathrm{BW})$ & $6 \cdot 0$ & $5.8^{*}$ & $6 \cdot 6^{*}$ & $7 \cdot 6^{*}$ & $0 \cdot 4$ & 0.044 \\
\hline \multicolumn{7}{|l|}{ Duodenum } \\
\hline (g) & 0.30 & $0.52^{*}$ & $0.69^{*}$ & $0.66^{*}$ & 0.03 & 0.011 \\
\hline$(\mathrm{g} / \mathrm{kg} \mathrm{BW})$ & 4.5 & $8 \cdot 4^{*}$ & $10 \cdot 1^{*}$ & $10-0^{*}$ & 0.7 & NS \\
\hline \multicolumn{7}{|l|}{ Caecum } \\
\hline (g) & 0.37 & $0.51^{*}$ & $0 \cdot 49^{*}$ & $0.61^{*}$ & 0.04 & 0.079 \\
\hline$(\mathrm{g} / \mathrm{kg} \mathrm{BW})$ & $5 \cdot 5$ & $8 \cdot 2^{*}$ & $7 \cdot 2^{*}$ & $9 \cdot 2^{*}$ & 0.5 & 0.066 \\
\hline \multicolumn{7}{|l|}{ Residual yolk sac } \\
\hline (g) & $7 \cdot 40$ & $5 \cdot 60^{*}$ & $4 \cdot 70^{*}$ & $5 \cdot 00^{*}$ & 0.82 & NS \\
\hline$(\mathrm{g} / \mathrm{kg} \mathrm{BW})$ & 110.4 & $90 \cdot 3^{*}$ & $69 \cdot 1^{*}$ & $75 \cdot 8^{*}$ & $11 \cdot 9$ & NS \\
\hline \multicolumn{7}{|l|}{ Pancreas } \\
\hline (g) & 0.05 & $0.08^{*}$ & $0.09 *$ & $0.08 *$ & $0 \cdot 001$ & NS \\
\hline$(\mathrm{g} / \mathrm{kg} \mathrm{BW})$ & 0.7 & $1 \cdot 3^{*}$ & $1 \cdot 3^{*}$ & $1 \cdot 2^{*}$ & 0.2 & NS \\
\hline \multicolumn{7}{|l|}{ Pancreatic $\alpha$-amylase activity } \\
\hline (U/g pancreas) & 247 & 372 & 295 & 290 & 33 & NS \\
\hline (U/g DM duodenal ingesta) & 2400 & $1080^{*}$ & $1150^{*}$ & $850^{*}$ & 103 & NS \\
\hline Plasma glucose $(\mathrm{mmol} / \mathrm{l})$ & $13 \cdot 7$ & $13 \cdot 6$ & $13 \cdot 7$ & $14 \cdot 4$ & 0.3 & 0.050 \\
\hline
\end{tabular}

BW, body weight; NS, not significant.

* Mean values were significantly different from those of birds at hatch, $P<0.05$

† For details of nutrients and procedures, see pp. 472-473.

$\ddagger$ The birds were administered a mixture of glucose, starch and oil (1:1:0.5 by vol.).

compared with those held without food for the first $24 \mathrm{~h}$. A single oral administration of the nutrient mixture immediately after hatch did not influence the latter variables, except for a slight but significant increase in the contents of the SI and caecum.

Irrespective of access to feed and water, the relative weight of the liver increased significantly $24 \mathrm{~h}$ after hatching, to a greater extent in the nutrient-administered birds $(P<0.063)$ compared with the immediate post-hatch birds (Table 3$)$. An opposite trend was observed for the residual yolk sac, such that its relative weight fell by $40-50 \% 24 \mathrm{~h}$ after hatching, to a greater extent in poults with immediate access to feed and water $(P<0.083)$. Whereas the relative weight of the pancreas increased significantly $24 \mathrm{~h}$ after hatching, more in the nutrient-administered poults $(P<0.086)$, the specific activity of pancreatic $\alpha$ amylase decreased considerably. Lower amylase activity ( $\mathrm{U}$ or $\mathrm{U} / \mathrm{kg} \mathrm{BW}$ ) was observed in poults with immediate access to feed and water compared with those held without food, and this effect was more pronounced in the nutrient-administered poults $(\mathrm{A} \times \mathrm{H}$ interaction effect, $P<0.007$, Table 3 ).

\section{Expt 2}

The effect of a forced oral administration of various doses on post-hatch poults was examined for $30 \mathrm{~h}$. The weights of the analysed GIT segments (crop, duodenum and caecum) with their respective contents increased significantly $24 \mathrm{~h}$ after hatching, and that 
Table 5. Expt 3. Gastrointestinal capacity (organ weights with ingesta), relative weights of the residual yolk sac and pancreas, and pancreatic $\alpha$-amylase (EC 3.2.1.1) activity in 24 h posthatch broiler chicks which received various nutrient levels in a single forced administration immediately after hatching $\dagger$

(Mean values with their pooled standard error for five or six birds per treatment group)

\begin{tabular}{|c|c|c|c|c|c|c|}
\hline \multirow[b]{2}{*}{ Dose administered $(\mathrm{ml}) \ddagger}$. & \multirow[t]{2}{*}{ At hatch } & \multicolumn{3}{|c|}{ 24-30 h post-hatch } & \multirow[b]{2}{*}{ SEM } & \multirow{2}{*}{$\begin{array}{l}\text { Significance } \\
\text { of } F \text { value }\end{array}$} \\
\hline & & 0 & 0.25 & 0.5 & & \\
\hline \multicolumn{7}{|l|}{ Organ weights (with ingesta) } \\
\hline \multicolumn{7}{|l|}{ Crop } \\
\hline (g) & $0 \cdot 26$ & $0.39 *$ & $0.31 *$ & $0.31 *$ & 0.02 & NS \\
\hline$(\mathrm{g} / \mathrm{kg} \mathrm{BW})$ & 3.8 & $5 \cdot 6^{*}$ & $6.0^{*}$ & $5 \cdot 7^{*}$ & 0.3 & 0.048 \\
\hline \multicolumn{7}{|l|}{ Duodenum } \\
\hline (g) & $0 \cdot 25$ & $0 \cdot 39 *$ & $0 \cdot 40^{*}$ & $0.47^{*}$ & 0.01 & 0.011 \\
\hline$(\mathrm{g} / \mathrm{kg} \mathrm{BW})$ & 5.0 & $8 \cdot 2^{*}$ & $8 \cdot 5^{*}$ & $10 \cdot 0^{*}$ & 0.5 & 0.030 \\
\hline \multicolumn{7}{|l|}{ Caecum } \\
\hline$(\mathrm{g})$ & 0.25 & $0.27^{*}$ & $0.28^{*}$ & $0.24^{*}$ & 0.02 & NS \\
\hline$(\mathrm{g} / \mathrm{kg} \mathrm{BW})$ & $5 \cdot 0$ & $5 \cdot 7^{*}$ & $6 \cdot 1^{*}$ & $5 \cdot 1^{*}$ & $0 \cdot 3$ & NS \\
\hline \multicolumn{7}{|l|}{ Residual yolk sac } \\
\hline (g) & 7.9 & $5 \cdot 7^{*}$ & $5 \cdot 1^{*}$ & $4 \cdot 9^{*}$ & 0.5 & NS \\
\hline$(\mathrm{g} / \mathrm{kg} \mathrm{BW})$ & 156 & $120^{*}$ & $109^{*}$ & $104^{*}$ & 22 & NS \\
\hline \multicolumn{7}{|l|}{ Pancreas } \\
\hline$(\mathrm{g})$ & $0 \cdot 04$ & $0.05 *$ & $0.06^{*}$ & $0.04^{*}$ & 0.001 & NS \\
\hline$(\mathrm{g} / \mathrm{kg} \mathrm{BW})$ & $0 \cdot 8$ & $1 \cdot 1^{*}$ & $1 \cdot 3^{*}$ & $0.9^{*}$ & $0 \cdot 2$ & NS \\
\hline \multicolumn{7}{|l|}{ Pancreatic $\alpha$-amylase activity } \\
\hline (U/g pancreas) & 390 & $402 *$ & $800^{*}$ & $580^{*}$ & 70 & 0.040 \\
\hline (U/g DM duodenal ingesta) & 3850 & $1700^{*}$ & $1100^{*}$ & $1500^{*}$ & 153 & NS \\
\hline Plasma glucose $(\mathrm{mmol} / \mathrm{l})$ & $13 \cdot 1$ & $13 \cdot 1$ & $12 \cdot 4$ & 13.8 & 0.3 & NS \\
\hline
\end{tabular}

BW, body weight; NS, not significant.

* Mean values were significantly different from those of birds at hatch, $P<0.05$.

+ For details of nutrients and procedures, see pp. 472-473.

$\ddagger$ The birds were administered a mixture of glucose, starch and oil $(1: 1: 0 \cdot 5$ by vol.).

of the yolk sac decreased compared with the immediate post-hatch birds (Table 4). Whereas the relative weight of the pancreas increased significantly $24 \mathrm{~h}$ after hatching, approximately twofold, no significant differences were noted in the specific activity of pancreatic $\alpha$ amylase. However, in the duodenal ingesta a marked decrease in the activity of $\alpha$-amylase was observed.

A single administration of various doses of the mixture generally influenced GIT contents during the post-hatch period (Table 4). Higher amounts of administered nutrients increased crop $(P<0.022)$, duodenum $(P<0.011)$ and caecum $(P<0.079)$ weights in a dose-dependent manner. Plasma glucose levels increased slightly $(P<0.05)$ with increasing levels of administered nutrients. No significant effects were noted in the residual yolk weight, pancreas weight or pancreatic amylolytic activity, with increased levels of administered nutrients (Table 4).

\section{Expt 3}

The relative weights of GIT segments increased significantly in $24-30 \mathrm{~h}$ post-hatch chicks compared with the immediate post-hatch ones (Table 5). The weight of the yolk sac and $\alpha$ amylase activity in the duodenal ingesta decreased compared with the immediate (i.e. $0-6 \mathrm{~h}$ ) post-hatch birds.

Administration of increasing amounts of nutrient mixture significantly increased the 
weights of the fore GIT (crop and duodenum) in a dose-dependent manner, but not of the caecum (Table 5). The activity of $\alpha$-amylase in the pancreas but not in the duodenal ingesta, increased significantly with nutrient administration. Blood plasma glucose was not affected by the administered nutrients.

\section{DISCUSSION}

Results of the preliminary study indicated that the water-administered group did not differ significantly from the non-administered group (Table 1). Furthermore, the effect of a single post-hatch administration of nutrients on subsequent early performance was studied in a previous study (Noy \& Pinchasov, 1993). Because one of the experimental groups was intubated with oil, the control group was assigned as non-intubated rather than waterintubated controls. We were consistent to that manner in the present study, and a similar non-intubated control was used here.

Post-natal development of the GIT was examined in domestic birds during the $30 \mathrm{~h}$ period after hatching. Results of the present study demonstrate progressive changes in GIT development during this post-hatch period (Tables 3-5). Two variables, the content of the GIT and the amylolytic capability of the pancreas, were chosen to examine whether forced oral administration of nutrients immediately after hatching induces anatomical and metabolic changes in the digestive system earlier than in birds with late access to feed. Whereas the growth of the pancreas and its amylolytic activity were only slightly influenced (Table 3), that of the GIT was markedly changed (Tables 4 and 5). Despite the rapid growth of the pancreas, the activity of $\alpha$-amylase in the pancreas $(\mathrm{U} / \mathrm{g})($ Table 3$)$ and that in the duodenal ingesta ( $\mathrm{U} / \mathrm{g}$ dry matter) (Tables 4 and 5 ) decreased significantly by day 2 , irrespective of the various treatments, compared with post-hatch birds. A similar pattern has been reported for pancreatic dipeptidases in chicks (Tarvid, 1992), and pancreatic $\alpha-$ amylase (Pinchasov \& Noy, 1994) and intestinal disaccharidases (Sell et al. 1991) in poults. The marked decrease in the activities of these digestive enzymes at the beginning of the post-natal period reconfirms the slightly limited amylolytic capability of the newly hatched broiler chicks and turkey poults. The slightly but significantly lower amylase activities (in $\mathrm{U}$ or $\mathrm{U} / \mathrm{kg} \mathrm{BW}$ ) observed in the nutrient-administered poults, more pronounced in those having immediate access to feed (Table 3), indicate that the secretion of amylase immediately after hatching is only slightly dependent on the presence of feed in the lumen, in accordance with findings for other pancreatic digestive enzymes in chicks (Tarvid, 1992).

Forced oral administration of nutrients into the crop immediately after hatching has been shown to promote subsequent growth in birds (Kienholz \& Ackerman, 1970; Waldroup et al. 1974; Phelps et al. 1987; Moran, 1990; Pinchasov \& Noy, 1992). Phelps et al. (1987) speculated that oral intubation stimulates mechano- and/or chemoreceptors in the GIT, resulting in enhanced consumption, whereas an alteration in glucogenic metabolism was proposed by Donaldson et al. (1992). In agreement with Donaldson et al. (1992), the results of the present study show that GIT weight and its contents increase in both species, in a dose-dependent manner, with nutrient administration (Tables 4 and 5). It may be suggested that post-hatching exposure of the digestive system by the forced administration of a nutrient mixture induces anatomical and metabolic changes in the digestive system slightly earlier than in birds with late access to feed. This increases GIT content and plasma glucose levels (Table 4), resulting in enhanced feed consumption and growth promotion (Noy \& Pinchasov, 1994).

The rapid transition from embryonic nutrition to exogenous, dietary-based neonatal nutrition is characterized by a transition from yolk lipid as energy source to dietary carbohydrate, and has been reported to alter glucogenic metabolism (Moran, 1990; Donaldson et al. 1992; Warriss et al. 1992). It should be noted that the relative weight of 
the residual yolk sac decreased by 40 to $50 \%, 24-30 \mathrm{~h}$ after hatching, irrespective of the presence of feed (Tables 3 and 5). A similar pattern of depletion has been reported in other studies (Daly \& Peterson, 1990; Nitsan et al. 1991; Chamblee et al. 1992; Murakami et al. 1992), indicating the yolk's crucial role in complementing early energy needs for rapid posthatch growth. The liver, in contrast, increased its relative weight during that period (Table 3), due to the massive transport of lipids from the residual yolk sac (Noble \& Cocchi, 1990).

\section{REFERENCES}

Bernfeld, P. (1955). Amylases $\alpha$ and $\beta$. In Methods in Enzymology, vol. 1, pp. 149-153 [S. B. Colowick and N. O. Kaplan, editors]. New York: Academic Press.

Chamblee, T. N., Brake, J. D., Schultz, C. D. \& Thaxton, J. P. (1992). Yolk sac absorption and initiation of growth in broilers. Poultry Science 71, 1811-1816.

Daly, K. R. \& Peterson, R. A. (1990). The effect of age of breeder hens on residual yolk fat, and serum glucose and triglyceride concentrations of day-old broiler chicks. Poultry Science 69, 1394-1398.

Donaldson, W. E., Brewer, C. E., Ferket, P. R. \& Christensen, V. L. (1992). Posthatch carbohydrate feeding and subsequent performance of turkey poults. Poultry Science 71, 128-132.

Donaldson, W. E. \& Christensen, V. L. (1992). Effects of injections of L-alanine, L-glucose and L-ascorbic acid in newly-hatched turkey poults on glucose metabolism. Comparative Biochemistry and Physiology A 101, 849-852.

Kienholz, E. W. \& Ackerman, R. V. (1970). Oral food slurry injection for newly hatched poults. Poultry Science 49, 678-680.

Moran, E. T. Jr. (1990). Effects of egg weight, glucose administration at hatch, and delayed access to feed and water on poult at 2 weeks of age. Poultry Science 69, 1718-1723.

Murakami, H., Akiba, Y. \& Horiguchi, M. (1992). Growth and utilization of nutrients in newly-hatched chick with or without removal of residual yolk. Growth Development and Aging 56, 75-84.

Nitsan, Z., Benavraham, G., Zoref, Z. \& Nir, I. (1991). Growth and development of the digestive organs and some enzymes in broiler chicks after hatching. British Poultry Science 32, 515-523.

Noble, R. C. \& Cocchi, M. (1990). Lipid metabolism and the neonatal chicken. Progress in Lipid Research 29, $107-140$.

Noy, Y. \& Pinchasov, Y. (1993). Effect of a single posthatch intubation of nutrients on subsequent early performance of broiler chicks and turkey poults. Poultry Science 72, 1861-1866.

Phelps, P. V., Gildersleeve, R. P. \& Edens, F. W. (1987). Effect of prefeeding on physiological parameters associated with turkey poult mortality. Poultry Science 66, 1882-1884.

Pinchasov, Y. \& Noy, Y. (1992). A single post-hatch intubation of various nutrients improves subsequent early performance of young birds. Proceedings 19th World's Poultry Congress, Amsterdam 19-24 September 1992 3, 614-618 (Abstr.).

Pinchasov, Y. \& Noy, Y. (1993). Comparison of post-hatch holding time and subsequent early performance of broiler chicks and turkey poults. British Poultry Science 34, 111-120.

Pinchasov, Y. \& Noy, Y. (1994). Early postnatal amylolysis in the gastrointestinal tract of turkey poults Meleagris gallopavo. Comparative Biochemistry and Physiology A 107, 221-226.

Proudfoot, F. G. (1982). Effect of hatching egg size from semi-dwarf and normal maternal meat parent genotypes on performance of broiler chickens. Poultry Science 61, 655-660.

SAS Institute (1985). SAS ${ }^{R}$ User's Guide: Statistics, 5th ed. Cary, NC: SAS Institute Inc.

Sell, J. L., Angel, C. R., Piquer, F. J., Mallarino, E. G. \& Al-Batshan, H. A. (1991). Developmental patterns of selected characteristics of the gastrointestinal tract of young turkeys. Poultry Science 70, 1200-1205.

Tarvid, I. (1992). Effect of early postnatal long-term fasting on development of peptide hydrolysis in chicks. Comparative Biochemistry and Physiology A 101, 161-166.

Waldroup, P. W., Hillard, C. M., Grigg, J. E. \& Harris, G. C. Jr (1974). The effectiveness of nutrient solutions given to young turkey poults in drinking water by oral and parenteral dosage. Poultry Science 53, $1056-1060$.

Warriss, P. D., Kestin, S. C. \& Edwards, J. E. (1992). Responses of newly hatched chicks to inanition. Veterinary Record 130, 49-53.

Whiting, T. S. P. (1984). Broiler performance and hatching egg weight to marketing weight relationships of progeny from standard and dwarf broiler dams. Poultry Science 63, 425-429.

Wyatt, C. L., Weaver, W. D. \& Beane, W. L. (1985). Influence of egg size, eggshell quality and posthatch holding time on broiler performance. Poultry Science 64, 2049-2055. 